\title{
An Overview on Role of Yellow Maize in Food, Feed and Nutrition Security
}

\author{
Jyoti Kaul $^{1 *}$, Khushbu Jain ${ }^{2}$ and Dhirender Olakh ${ }^{2}$ \\ ${ }^{1}$ ICAR-Indian Agricultural Research Institute, Pusa, New Delhi 110 012, India \\ ${ }^{2}$ ICAR-Indian Institute of Maize Research, Pusa, New Delhi 110 012, India \\ *Corresponding author:
}

\section{Keywords}

Yellow maize, $\beta$ carotenes and Xanthophylls, Nutrition security

Article Info

Accepted:

22 January 2019

Available Online:

10 February 2019

\section{A B S T R A C T}

Maize, Zea mays L., is one of the important cereal crops with diverse uses as food, feed, fodder and industrial applications. As a food crop it is a primary source of nourishment to people in Africa, Latin America and South Asia. It is also the principal energy source used in poultry diets in most of the countries including India because of its high-energy value, palatability, presence of pigments and essential fatty acids. Yellow kernelled cultivars are preferred as poultry feed as it is a rich source of $\beta$-carotenes and xanthophylls conferring yellow colour for colouration of egg yolk, poultry fat and skin. Maize also contains highest amount of energy among cereal grains and has high TDN of $85-90 \%$. By virtue of these advantages, maize is known as nutri-cereal. It is however, deficient in two essential amino acids namely lysine and tryptophan but with the discovery of opaque mutants, these deficiencies were overcome through the breeding of opaque varieties which later paved way to the development of Quality Protein Maize (QPM). The nutritionally enriched QPM kernels contain double the quantity of lysine and tryptophan, balanced ratio of isoleucine to leucine and increased desirable proteins viz. albumins, glutelins and globulins in their endosperm. With its development, new vistas were opened up for achieving food and nutrition security of the under-privileged masses. In this mini-review, role of yellow maize in general and QPM in particular in augmenting food, feed and nutrition security especially in Indian context is discussed.

\section{Introduction}

Among the various cereals, maize (Zea mays L.) also called poor man's nutri-cereal, is a crop of opportunities as it has multiple uses as food, feed and industrial applications. As a food crop it provides about $30 \%$ of the calories for approximately 4.5 billion people in 94 developing countries. Globally, 63\% of maize is also used for livestock feed besides being an important source of oil, starch, biofuel, etc (Shiferaw et al., 2011). Currently, the United States, Brazil, Mexico, Argentina, India, France, Indonesia, South Africa, and Italy produce $79 \%$ of the world's maize (FAO, 2019).

In India, maize is among the three most important cereal crops that caters to the country's diverse needs (poultry feed, nutrifoods and industrial applications) because of which it registered very high growth rate 
particularly in last 1-2 decades (Kumar et al., 2013). As per latest FAO estimates, the crop occupied an area of 9.22 mha producing 28.72 mt with an average productivity of 3.11 tons/ha in 2017 (FAO, 2019).Based on the prediction by International Food Policy Research Institute (IFPRI), maize demand is expected to overtake that of wheat and rice by 2020 and that a large proportion of the increased demand, $72 \%$, will come from developing countries. Within developing countries the highest proportion of maize will be used for food in countries of Sub Saharan Africa (76\%) and South Asia (70\%).Whereas East Asian countries would be using highest proportion, $82 \%$, as feed and $14 \%$ for industrial uses, respectively (IPFRI, 2002; FAO, 2009). In order to meet the increasing demand, emphasis is being laid on developing and disseminating high yielding cultivars with resistance to biotic and abiotic stresses. Being highly cross -pollinated, maize offers the opportunity to exploit heterosis and hence globally the breeding strategy emphasizes evolving hybrids especially single cross hybrids (SCHs) suitable for different production ecologies.

\section{Maize utilization}

The diverse utilization of maize may be ascribed to its kernel colour and texture. The cultivars with yellow / yellow-orange/ orange kernels (collectively known as yellow maize) are generally preferred as poultry feed and white as human food. Historically maize was used more for local consumption. Over the last two- three decades, its direct food usage is on the decline due to number of reasons including rising income levels and change in food habits. Concurrently, the use of maize in poultry feed and industrial applications have gone up. Yellow kernelled cultivars are preferred as poultry feed as it is a rich source of $\beta$-carotenes and xanthophylls conferring yellow colour for colouration of egg yolk, poultry fat and skin when it is used at $30 \%$ and above in the diet. Because of these reasons, maize augments booming poultry industry and feed nutrition security. The kernel texture in maize is represented by flint (F), semi-flint (SF), dent (D) and semi-dent (SD), respectively. Flints or SFs are known for their suitability for use in livestock feed and possess added advantage of storing well under harsh growing conditions. Bedsides higher grain yield, D and SDs have soft starch and hence are amenable to industrial processing as well (Gwirtz and Garcia-Casal, 2014).

\section{Maize kernel composition and anatomy}

In general, maize kernel is a good source of carbohydrates, fats, proteins and some of the important vitamins and minerals. Especially the macro-and micro-nutrients in maize kernel contribute significantly to its enhanced food and feed quality (Watson, 2003). Besides, maize also contains highest amount of energy (ME $3350 \mathrm{kcal} / \mathrm{kg}$ ) among cereal grains. Therefore, maize is termed as nutricereal.The status of macro-molecules in Indian maize genotypes is given in Table 1. In general, maize genotypes of Indian origin are known to have $\sim 67-72 \%$ starch, $12-15 \%$ moisture, 8-12\% protein, $2-4 \%$ fat, $2-3 \%$ fibre and around $1.5 \%$ minerals.

The maize kernel is composed of four primary structures: endosperm, germ, pericarp, and tip cap, making up $83 \%, 11 \%, 5 \%$, and $1 \%$ of the kernel, respectively. The endosperm is primarily composed of starch and is surrounded by a protein matrix. Two main types of starch include hard or vitreous, and soft or opaque. Former is negatively related to starch degradability and in vivo starch digestibility in ruminants. The germ or embryo of the maize kernel is high in fat $(\sim 33.3 \%)$ in addition to enzymes and nutrients for growth and development of new maize 
plant. Nearly $80 \%$ of the kernel's minerals are contained in the germ while the endosperm has $<1 \%$. Phosphorus (in the form of phytate), potassium, and magnesium are the three-most prevalent minerals found providing nearly $85 \%$ of kernel mineral content. The fourth most abundant element is sulfur, mostly present in an organic form as a constituent of methionine and cystine. The germ also contains antioxidants such as vitamin E. Pericarp is a high-fiber ( $~ 8.8 \%$ crude) semipermeable barrier surrounding the endosperm and germ, covering all but the tip cap. The tip cap is the structure through which moisture and nutrients pass through during development and kernel dry down period. The black layer or hilum on the tip cap acts as a seal. Maize kernel is amenable to manipulations that affect its nutritional value as its composition is largely controlled by genetics of the endosperm sink, maternal parent and the environment (Nuss and Tanumihardjo, 2010).

Variations in maize may also be defined according to kernel texture as follows: dent, flint, waxy, flour, sweet, pop and pod corn. Except for pod corn, these divisions are based on the quality, quantity, and pattern of endosperm composition, which defines the size of the kernel and are not indicative of natural relationships. Endosperm composition may be changed by a single gene difference, as in the case of floury $(f l)$ versus flint $(F I)$, sugary $(s u)$ versus starchy $(S u)$, waxy $(w x)$ versus nonwaxy $(W x)$, and other single recessive gene modifiers that have been used in breeding special-purpose maize, viz. sweet corn, popcorn, waxy maize, etc.

\section{Maize and nutrition}

Despite the world-wide increase of food availability, there are still around 800 million people undernourished. Vast majority of this is from Sub Saharan Africa and developing countries of the world. Asia as a whole has a prevalence of undernourishment of $12.7 \%$ corresponding to 526 million people with large differences across its sub- regions. India has made significant progress in improving food security of its masses. The green revolution of 60's helped the country in achieving food security through improving the availability and access components. However, the availability dimension addressed the quantity, but not the quality of food i.e. nutrition. Even though there has been surplus of food grains at national level, yet addressing malnutrition i.e. hidden hunger has remained a daunting aspect of nutrition security.

\section{Discovery of opaque-2 gene and development of Quality Protein Maize (QPM)}

The quality of maize protein is poor due to the presence of large concentration of an alcohol soluble protein fraction, prolamines also known as zeins. The zein proteins located in endosperm are very low in lysine and tryptophan contents and since this fraction contributes $>50 \%$ of the total protein, the maize protein is, therefore, deficient in these amino acids. Also, zein contains very high amount of leucine and imbalanced proportion of isoleucine as well. The ill- proportion of four essential amino acids in kernels results in poor protein quality affecting its biological value i.e. the availability of protein to the body. In addition commonly available maize or Normal Maize (NM) lacks vitamin B and also due to high concentrations of phytate, bioavailability of some minerals in the grain is low.

Globally, the research on various aspects of protein quality was initiated during mid 1960's when certain mutants were identified in the experimental fields of Connecticut, USA that later showed higher levels of lysine 
in their grains due to the presence of gene called opaque 2 (Mertz et al., 1964).Following the discovery of $f l 2$ and other mutations in 1960s, several studies were conducted to investigate the nutritional value of these mutants. The observation that lysine and tryptophan contents were double than that in common maize eventually prompted the breeding of opaque 2 varieties. The deployment of such varieties on farmers' fields, however, met with little success. Despite the higher amino acid levels, the soft, chalky endosperm characteristic of these mutations was more susceptible to fungal ear rots, lower yielding, and unappealing to maize growers. With the discovery of opaque 2 modifier genes, maize breeders at CIMMYT took up conventional breeding programmes that improved the agronomic shortcomings and amino acid contents through backcrossing and recurrent selection and were able to produce higher yielding, lysine / tryptophan rich germplasm that lacked the characteristic opaque endosperm. Such germplasm was designated as Quality Protein Maize (Vasal, 2000; 2001).Quality Protein Maize (QPM) was evolved by selecting genetic modifiers, multiple, unlinked opaque modifiers (OPM) that convert the starchy endosperm of an opaque 2 mutant to a hard, vitreous phenotype. The QPM genotypes are homozygous for opaque- 2 gene and have endosperm modifiers that provide grain texture similar to NM. In QPM the concentration of zein is lowered by $\sim 30$ percent, as a result lysine and tryptophan contents double in the endosperm proteins and the protein quality shows remarkable improvement over normal counterparts. The lower contents of leucine further balance the ratios of leucine to isoleucine. The balanced proportion of all these essential amino acid enhances the biological value of protein. The true protein digestibility is almost same, but the biological value of QPM is just double as compared to NM (Vasal et al., 1993).
Improving its protein quality therefore, has been one of the major objectives of Indian breeding programmes. The status of protein quality measures in Indian maize genotypes of NM and QPM is summarized in Table 2. A perusal of data indicated the abundance of prolamines (undesirable protein fraction) in NM which is reduced to half in QPM genotypes.

\section{QPM and nutrition security}

With the development of QPM cultivars, new vistas were opened up for achieving food and nutrition security of the under-privileged masses especially in Sub-Saharan Africa, Latin America and South Asia (Prasanna et al., 2001). Globally, dissemination of QPM is recognized as a step towards seeking nutrition security among economically deprived sections of the societies as it is cheaper, more affordable and easy to produce compared to animal protein (Gupta et al., 2009). The protein quality in terms of \% casein is highest in opaque-2 followed by QPM than NM and some other important cereals. This information has been compiled in Table 3 . Agronomically, the opaque 2 varieties failed on farmers' fields due to a number of reasons including low yield, chalky soft grains and greater vulnerability to stored insect-pests despite its superior protein quality. QPM, on the other hand, displayed promise in tackling nutrition-related issues and has elicited keen interest amongst marginalized farming communities. Hence, breeding and production of QPM stands out as an alternative protein source for poor-resource farming/ tribal communities. It has the potential to fulfill the protein requirements of different sections of society, viz. infants, lactating mothers, convalescing patients, Kwashiorkor diseased, old persons and infirm, etc. It can also be effectively utilized for diversified purposes as health food/mixes, convenience foods, specialty foods and emergency ration. 
Nutritional studies have demonstrated that QPM consumption can reduce or prevent stunted growth in young children whose diets are heavy in maize (Gunaratne et al., 2010). The products developed from QPM can also replace fancied and highly priced industrial foods. These can also be prepared in villages and thus could be a great source of rural entrepreneurship as well.

By virtue of its balanced amino acid profile, QPM has opened a new opportunity in the area of animal nutrition as well. The global shift in cereal demand favoring maize reflects rising incomes with consequent growth in meat consumption which drives demand for maize as a major feed crop. The projections have indicated $30 \%$ increase in global demand for monogastric animals like poultry and pork. The poultry industry is seeking maize with improved amino acids and oil content (Hellin and Erenstein, 2009). To exploit fully their genetic potential, balanced diets are required (Ignjatovic-Micic et al., 2013). Nutritionally enhanced QPM augmented with oil therefore has potential for replacing more expensive dietary sources of fats and proteins. In animal feed, a high oil concentration in kernels is desirable since the calorific value of oil is higher than that of starch with better utilization of oil and protein (Saleh et al., 1997; Yin et al., 2002). The experiments of dietary replacement of NM by QPM demonstrated significant increase in the weight gain of broilers with greatly improved feed efficiency. In broiler diet, the substitution of QPM for NM at a rate of $60 \%$ substantially reduces the need for soybean meal and therefore the cost (Subsuban et al., 1990). Similarly, in an experiment with finisher pigs, less soybean meal was needed to maximize performance in diets based on QPM compared with diets having NM. Linear programming models allow feed companies to identify the cheapest way of providing the minimum dietary requirements for farm stock.
Calculations for pig and poultry ration containing NM, QPM, sorghum, soybeans meal and synthetic lysine and tryptophan showed that the usage of QPM in place of maize resulted in saving of $2.8 \%$ on chickens feed and $3.4 \%$ on pig feed (Lopez-Pereira, 1992). Studies have also documented improved growth in pigs when QPM is substituted for conventional maize thereby increasing the bio- available protein (Mbuya et al., 2011; Yongfeng and Jay-Lin, 2016). Thus, QPM can reduce the cost of animal feed by decreasing the expenditure incurred on more expensive high protein sources.

\section{Exogenous vs. endogenous fortification}

Foods such as flour, salt, sugar, and cooking oil, have been frequent vehicles for food fortification by adding essential vitamins and minerals. But this is expensive, unpopular as well as un-economical. Recent advances focused on staple crop enrichment, such as maize and maize-based food products. QPM provides an ideal germplasm - base upon which a number of nutritionally important traits such as Fe, Zn, oil, carotenes, tocopherols, methionine, etc could be combined to strengthen breeding of nutrientenriched biofortified maize (Vallabhaneni et al., 2009; Kuhnen et al., 2009; Jaradat and Goldstein, 2013, 2018; Changan et al., 2017). With some identified donors for high nutrients, varieties are being developed through conventional breeding by crossing with popular varieties. Recent approaches for biofortification include identification of genomic regions/candidate genes for high nutrients through tagging/identification of major genes or mapping of quantitative trait loci (QTL) followed by their introgression into popular varieties. Being a genetic solution, growing biofortified crops does not require any additional expenditure by farmers as this approach uses intrinsic properties of crops. In India, biofortified crops have been 
developed circumventing transgenic approach through conventional and molecular breeding, and therefore, regulatory constraints are not applicable for their release. Hence, endogenous fortification by way of varietal development with target traits remains the best option.

\section{Varietal development in maize (and QPM) in India}

With the launch of All India Coordinated Maize Improvement Project (AICMIP) later re-christened as All India Coordinated Research Project on maize (AICRP on maize) in 1957 at Pusa Campus, New Delhi, a strong foundation for systematic varietal development was laid (Dhillon et al., 2006). Between 1961 and 2017, a total 348 cultivars of maize emanated from public and proprietary breeding programmes in the country (Kaul et al., 2017). Majority of the released cultivars are of NM type possessing yellow F / SF kernels. Besides, a small percentage of white OPVs and hybrids have also been bred. The quality breeding has been the forte of public institutions in India. In the pursuit of developing quality hybrids, an increased emphasis is being laid on developing genetically diverse inbred lines with improved protein quality as well as agronomic performance. Many breeding centres made use of diverse source germplasm like hybrids, populations, segregating lines, etc and extracted hundreds of lines of early, medium or late maturity varying in kernel texture and with resistance to biotic stresses, e.g. Maydis leaf blight (MLB), Turcicum leaf blight (TLB) and charcoal rot (CR) and tolerance to abiotic stresses viz. drought, etc. The most desirable inbreds have been used in 2- parent combinations and the best combinations have been released as commercial QPM hybrids. Till date, more than a dozen SCHs of QPM have been released for cultivation. These hybrids possess higher contents of tryptophan ranging between $0.67 \%$ and $1.08 \%$ (in endosperm proteins) while protein contents range from $8.86 \%$ to $10.80 \%$, respectively. The information on quality traits in released hybrids of yellow QPM is given in Table 4. Besides, some of the promising lines have also been registered at ICAR-NBPGR, New Delhi so as to facilitate sharing of germplasm / expediting of inbred-hybrid technology in the country (Table 5).

\section{Maize processing}

Maize with increased protein quality i.e. QPM has high nutritional value for human food, animal feed, and industrial processing. Maize is an integral component in making both food as well as non-food industrial products which have good commercial value. Large-scale maize processing produces a large number of industrial products and also provides more employment opportunities.

Maize is usually processed by two distinct processes, namely dry milling and wet milling. Former involves the maize kernels to be screened, tempered with hot water/steam to loosen the germ and bran. This is followed by removal of germ. The husk is separated by means of aspirators. The degermed maize is subjected to milling to produce grits, meal and flour. Dry milling produces grits, com flour, and a minimum amount of com meal as well. Maize is generally processed to manufacture cornstarch by wet milling method. The by-products of starch manufacture like com oil, com steep liquor, gluten etc. are important value added products. Wet milling process involves the splitting of the grain into four main components, namely germ, bran (or fibre), gluten and starch in sequence. Maize starch is extensively used as a sizing material in the textile and paper industries. In the food industry, it is used in the preparation of pies, 
puddings, salad dressings and confections. Maize starch is also used for the production of dextrose and com syrup. Various food technologies are currently used for processing industrially produced maize flours and corn meals in different parts of the world to obtain precooked refined maize flour, dehydrated nixtamalized flour, fermented maize flours, and other maize products. These products have different intrinsic vitamin and mineral contents. All the major sweeteners are commercially made from maize starch.

In conclusions, nutritional insecurity is among the major threats to the growing population especially in the developing countries of the world. Maize is a good source of vitamins, minerals, starch, sugar and dietary fiber among many nutrients.

Table.1 Status of macromolecules in Indian maize genotypes

\begin{tabular}{|l|c|c|c|}
\hline Parameter & Range (\%) & Parameter & Range (\%) \\
\hline Starch & $67-72$ & Sugar & $2-6$ \\
\hline Protein & $8-12$ & Oil & $1-5$ \\
\hline Fat & $2-4$ & Fibre & $2-3$ \\
\hline
\end{tabular}

Table.2 Status of various protein fractions and amino acids in NM and QPM kernels of Indian genotypes

\begin{tabular}{|l|c|c|}
\hline Protein / amino acid & NM (\%) & QPM (\%) \\
\hline Albumins & 3.2 & 13.2 \\
\hline Globulins & 1.5 & 3.9 \\
\hline Prolamines & 47.2 & 22.8 \\
\hline Glutelins & 35.1 & 50.0 \\
\hline Tryptophan & 0.3 or less & 0.6 or more \\
\hline Lysine & $1.2-1.5$ & 2.4 or more \\
\hline
\end{tabular}

Source: Anonymous, 2010

Table.3 Protein quality in different types of maize vis a vis other cereals

\begin{tabular}{|c|c|c|c|}
\hline Cereal & $\begin{array}{c}\text { Protein quality } \\
\text { (\% casein) }\end{array}$ & Cereal & $\begin{array}{c}\text { Protein quality } \\
\text { (\% casein) }\end{array}$ \\
\hline Rice & 79.3 & Sorghum & 32.5 \\
\hline Wheat & 38.7 & Barley & 58.0 \\
\hline $\begin{array}{c}\text { Normal } \\
\text { maize(NM) }\end{array}$ & $\mathbf{3 2 . 1}$ & Pearl millet & 46.4 \\
\hline Opaque-2 maize & $\mathbf{9 6 . 8}$ & Finger millet & 35.7 \\
\hline QPM & $\mathbf{8 2 . 1}$ & Teff & 56.2 \\
\hline Oats & 59.0 & Rye & 64.8 \\
\hline
\end{tabular}


Table.4 Protein and tryptophan contents in yellow QPM hybrids released in India

\begin{tabular}{|l|c|c|}
\hline \multicolumn{1}{|c|}{ Hybrid } & Protein (\%) & Tryptophan (\%) \\
\hline Pusa VQPM9 improved* & 9.37 & 0.74 \\
\hline Pusa HM9 improved & 10.50 & 0.68 \\
\hline Pusa HM4 improved & 10.80 & 0.91 \\
\hline Pusa HM8 improved & 10.50 & 1.06 \\
\hline Pratap QPM1 & 10.57 & 0.67 \\
\hline HQPM 1 & 10.09 & 0.79 \\
\hline HPQM 4 & 10.30 & 0.67 \\
\hline HPQM 5 & 10.15 & 0.69 \\
\hline HQPM-7 & 9.80 & 0.72 \\
\hline VQPM -9 & 9.20 & 0.70 \\
\hline Shaktiman-3 & 9.27 & 0.70 \\
\hline Shaktiman-4 & 8.86 & 0.67 \\
\hline
\end{tabular}

Table.5 Characteristics of unique lines of QPM registered at ICAR-NBPGR

\begin{tabular}{|c|c|c|c|c|c|}
\hline s.\# & Lines & $\begin{array}{l}\text { Source } \\
\text { germplasm }\end{array}$ & INGR \# & $\begin{array}{l}\text { Breeding } \\
\text { centre }\end{array}$ & Major traits \\
\hline 1 & DQL 2105-1 & HQPM7 & 17013 & IIMR & $\begin{array}{l}\text { Source of resistance to } \\
\text { MLB and TLB }\end{array}$ \\
\hline 2 & DQL 2048 & HQPM1 & 17014 & IIMR & $\begin{array}{l}\text { Source of resistance to } \\
\text { MLB and TLB }\end{array}$ \\
\hline 3 & DQL 1019 & HQPM1 & 17023 & IIMR & Source of resistance to CR \\
\hline 4 & DMRQPM58 & Shakti -1 & 14012 & DMR & $\begin{array}{l}\text { Early maturity, tryptophan } \\
0.66 \% \text { in protein }\end{array}$ \\
\hline 5 & $\begin{array}{l}\text { DMRQPM } \\
(03)-124\end{array}$ & Shakti-1 & 14013 & DMR & $\begin{array}{l}\text { Medium maturity, } \\
\text { tryptophan } 0.67 \% \text { in protein }\end{array}$ \\
\hline 6 & DMRQPM102 & CLQRCY 30 & 13074 & DMR & $\begin{array}{l}\text { Medium maturity, } \\
\text { tryptophan } 0.66 \% \text { and } \\
\text { moderately resistant to } \\
\text { MLB }\end{array}$ \\
\hline 7 & DMRQPM103 & CLQRCY41 & 13023 & DMR & $\begin{array}{l}\text { Early maturity, low ASI, } \\
\text { tryptophan } 0.67 \%\end{array}$ \\
\hline 8 & HKI 5072-2 BT & $\begin{array}{l}\text { DMRQPM50 } \\
72\end{array}$ & 10083 & Karnal & $\begin{array}{l}\text { Medium maturity, yellow, } \\
\text { flint, high tryptophan, } \\
\text { attractive grain colour, dark } \\
\text { green leaves }\end{array}$ \\
\hline 9 & DMRQPM-107 & CLQRCY47B & 10084 & DMR & $\begin{array}{l}\text { Medium maturity, yellow, } \\
\text { flint, high tryptophan, good }\end{array}$ \\
\hline
\end{tabular}




\begin{tabular}{|c|c|c|c|c|c|}
\hline & & & & & combiner, thin cob \\
\hline 10 & HKI-170(1+2) & CML170 & 09064 & Karnal & Late maturity, yellow, flint \\
\hline 11 & VQL-3 & - & 09012 & Almora & $\begin{array}{l}\text { Early maturity, orange, } \\
\text { flint, high tryptophan } \\
(>0.83 \%)\end{array}$ \\
\hline 12 & VQL-8 & - & 09013 & Almora & $\begin{array}{l}\text { Medium maturity, orange, } \\
\text { flint, high tryptophan } \\
(>0.94 \%)\end{array}$ \\
\hline 13 & VQL-12 & - & 09014 & Almora & $\begin{array}{l}\text { Early maturity, orange, } \\
\text { flint, high tryptophan } \\
(>0.75 \%)\end{array}$ \\
\hline 14 & VQL-16 & - & 09015 & Almora & $\begin{array}{l}\text { Early maturity, yellow, } \\
\text { flint, high tryptophan } \\
(>0.73 \%)\end{array}$ \\
\hline 15 & VQL-30 & - & 09016 & Almora & $\begin{array}{l}\text { Early maturity, orange, } \\
\text { flint, high tryptophan } \\
(>0.71 \%)\end{array}$ \\
\hline 16 & HKI-164D-4 & CML164 & 08076 & Karnal & $\begin{array}{l}\text { Late maturity, yellow and } \\
\text { semi-dent grain and MLB } \\
\text { resistant, QPM }\end{array}$ \\
\hline 17 & HKI-164-7-6 & CML164 & 08077 & Karnal & $\begin{array}{l}\text { Late maturity, orange and } \\
\text { semi-dent grain and MLB } \\
\text { resistant, QPM }\end{array}$ \\
\hline 18 & VQL-1 & $\begin{array}{l}\text { CM212 x } \\
\text { CML170 }\end{array}$ & 08011 & Almora & $\begin{array}{l}\text { Medium maturity, semi- } \\
\text { flint, yellow grains with } \\
\text { cap, high tryptophan } \\
(>0.6 \%)\end{array}$ \\
\hline 19 & VQL- 2 & $\begin{array}{l}\text { VL145 x } \\
\text { CML180 }\end{array}$ & 08012 & Almora & $\begin{array}{l}\text { Early maturity, flint, orange } \\
\text { grains, high tryptophan } \\
(>0.6 \%)\end{array}$ \\
\hline
\end{tabular}

The cost-benefit ratio of maize production is highest among the cereals because of its very high productivity while the economics of its cultivation is almost similar as that of sorghum and wheat. Since a lot of small-scale farmers are involved in maize farming, it makes it an affordable source of nourishment for people living in rural areas. QPM hybrid seed availability is an issue that concerns the public institutions as no private organizations have ventured into QPM research. So to solve the availability of quality seed, special attention has to be paid by developing regional seed hubs. Such alternative sites for seed production of QPM hybrids may be identified with requisite isolation distance, good connectivity of roads, assured irrigation and storage facilities.

In India, tribal population constitutes approximately $10 \%$ of the total population and is found in most parts of the country especially in the states of Madhya Pradesh, Assam, Gujarat, Chhattisgarh, Jharkhand, North east, etc. Tribal people are acknowledged to have very close association with ecosystem and environment because of their dependence on nature directly for daily requirements. However, the problem of malnutrition arises due to inadequate intake of 
nutrients in the diet. Further, most of tribal populations depend on maize as their basic diet. In these areas, therefore, substituting QPM for NM to ensure food and nutritional security is paramount. Several measures are urgently needed for popularizing QPM among the various stakeholders including farmers and end-users. For example, Government of India can make provisions to introduce QPM in public distribution system and QPM- based food in mid - day meal in schools and anganwadis. Hence, increasing the productivity and managing the quality aspects would immensely benefit the growers and consumers alike.

\section{References}

Anonymous, 2010. Annual Progress Report (Kharif 2010). All India Coordinated Research Project - Maize. Kumar, R. S., Kumar,., Kumar, P., Mahajan, V., Hooda, K.S., Shekhar, M., Paul, D., Singh, K.P., Singode, A., Parihar, C.M., Chikkappa, G.K., Suby, S.B., Jat, S.L., Sapna. (Eds.), Directorate of Maize Research, Pusa Campus, New Delhi110012, India. pp 607.

Changan, S., Chaudhary, D.P., Kumar, S., Kumar, B., Kaul, J., Guleria, S., Jat, S. L., Singode A., Tufchi, M., Langyan, S., Yadav, O. P., 2017. Biochemical characterization of elite maize (Zea mays) germplasm for carotenoids composition. Ind. J. Agril. Sci., 87 (1): 46-50.

Dhillon, B.S., and Malhi, N.S., 2006. Maize Breeding in India - Retrospective Analysis and Prospects. Ind. J. Pl. Genet. Resour., 19(3), 327-345.

FAO, 2002. The state of food and agriculture. Food and Agriculture Organization of the United Nations, Rome, 2002.

FAO, 2009. The state of Food and Agriculture. Livestock in the balance. IISN 0081-4539 (accessed at www.fao.org/catalog/inter-e.htm)

FAO, 2019. FAOstat 2017. (accessed at http://www.fao.org/faostat/en/\#data/QC

Gunaratna, N. S., De Groote, Hugo, Nestel, P., Pixley, K. V., McCabe, G., P. 2010. A meta-analysis of community-based studies on quality protein maize. Food Policy 35: 202-210 doi:10.1016/j.foodpol.2009.11.003.

Gupta, H. S., Agrawal, P. K., Mahajan,V., Bisht, G. S., Kumar, A., Verma, P., Srivastava, A., Saha, S. Babu, R. Pant, M. C., Mani, V. P., 2009. Quality protein maize for nutritional security: rapid development of short duration hybrids through molecular marker assisted breeding. Curr. Sci. 96: 230237.

Gwirtz, J. A. and Garcia-Casal, M. N. 2014. Processing maize flour and corn meal food products. Ann. N.Y. Acad. Sci., 1312: 66-75.

Hellin, J., Erenstein, O., 2009. Maize-Poultry Value Chains in India: Implications for Research and Development. J. New Seeds 10: 245-263. Doi $10.1080 / 15228860903303932$.

IFPRI, 2002. Global food projections to 2020 - emerging trends and alternative futures. (Accessed at www.ifpri.org)

Ignjatovic-Micic, D., Kostadinovic, M., Stankovic, G., Markovic, K., Vancetovic, J., Bozinovic, S., Andjelkovic, V., 2013. Biochemical and agronomic performance of quality protein maize hybrids adapted to temperate regions. Maydica, 58: 311317.

Jaradat, A. A., Goldstein, W., 2013. Diversity of maize kernels from a breeding program for protein quality: I. physical, biochemical, nutrient, and color traits. Crop Sci., 53:956-976.

Jaradat, A. A., Goldstein, W., 2018. Diversity of maize kernels from a breeding program for protein quality III: Ionome 
profiling. Agron. 8 (2), 9; doi:10.3390/agronomy8020009.

Kaul, J., Ramesh Kumar, U. Nara, K. Jain, DS Olakh, T. Tiwari, OP Yadav, Dass, S., 2017. Development of database of maize hybrids and open pollinated varieties released and notified for cultivation in India. J. Agril. Sci., 9(10): 105-113.

Kuhnen, S., Lemos, P.M.M., Campestrini, L.H., Ogliari, J.B., Dias, P.F., Maraschin, M., 2009. Antiangiogenic properties of carotenoids: a potential role of maize as functional food. J. Functional Foods 1: 284-290.

Kumar, R., Srinivas, K. and Sivaramane, N., 2013.Assessment of the maize situation, outlook and investment opportunities in India. Country report-Regional Assessment Asia (Maize-CRP) (p. 133). National Academy of Agricultural Research Management, Hyderabad, India.

Lopez-Pereira, M. A., 1992. The economics of quality protein maize as an animal feed: Case studies of Brazil and EI Salvador, CIMMYT, Mexico, DF.

Mbuya, K., Nkongolo, K., Kalonji-Mb, A., 2011. Nutritional analysis of quality protein maize varieties selected for agronomic characteristics in a breeding program. Intl. J. Pl. Breed. \& Genet. 5: 317-327 doi 10.3923/ijpbg.2011.317.327.

Mertz, E. T., Bates, L. S. and Nelson, O. E., 1964. Mutant gene that changes the protein composition and increases the lysine content of maize endosperm. Sci., 145: 279-280.

Nuss, E.T. and Tanumihardjo, S.A., 2010. Maize: A paramount staple crop in the context of global nutrition. Compre. Rev. Food Sci. and Food Safety 9: 417$436 . \quad$ doi: $\quad 10.1111 / \mathrm{j} .1541-$ 4337.2010.00117.x.

Prasanna, B.M.,Vasal, S.K.,Kassahun, B., and
Singh, N.N., 2001.Quality Protein Maize.Curr. Sci., 81, 1308-1319.

Saleh, E.A., Watkins, S.E., England, JA., Waldgroup, P.W., 1997. Utilization of high oil corn in broiler diets varying in energy content. J. Appl. Poultry Res., 6 (1):107-115.

Shiferaw, B., Prasanna, B.M., Hellin, J. and Banziger, M., 2011. Feeding a hungry world: past successes and future challenges to global food security in maize. Food Security, 3: 307-332.

Subsuban, C.P., Olanday, P.O., Cambel, I.H., 1990. Advantages of Quality Protein Maize (QPM) in broiler ration. Research and Development J. (Philippines), 1(1): 5-17.

Vallabhaneni, R., Gallagher, C. E., Licciardello, N., Cuttriss, A. J., Quinlan, R. F., Wurtzel, E. T., 2009. Metabolite sorting of a germplasm collection reveals the hydroxylase 3 locus as a new target for maize provitamin A biofortification. Pl. Physiol., 151: 1635-1645.

Vasal, S.K., 2000. The Quality protein maize story. Food and Nutrition Bulletin 21:445-450. doi: $10.1177 / 156482650002100420$.

Vasal, S. K., 2001. High quality protein corn, pp. 85-129. In: Specialty Corns. Hallauer AR ed. CRC Press, Baca Raton, FL.

Vasal, S. K., Srinivasam, G. S., Pandey; Gonzalez, F., Crossa, J., Beck, D. L., 1993. Heterosis and combining ability of CIMMYT's Quality Protein Maize germplasm I. Lowland tropical. Crop Sci., 33: 46-51.

Watson, S.A., 2003. Description, development, structure and composition of the corn kernel. In: White, P.J., Johnson, L.A. (Eds.), Corn: Chemistry and Technology, 2nd ed, pp. 69-101.

Yin, Y.L., Gurung, N.K., Jeaurond, E.A., Sharpe, P.H., and de Lange, C. F. M., 
2002. Digestible energy and amino acid contents in Canadian varieties of sorghum, pearl millet, high-oil corn, high-oil-high-protein corn and regular corn samples for growing pigs. Canad. J. Anim. Sci. 82(3): 385-91.
Yongfeng, A., and Jay-Lin, J., 2016. Macronutrients in corn and human nutrition. Compre. Reviews Food Sci. Food safety, 15: 581-598. doi.org/10.1111/1541-4337.12192.

\section{How to cite this article:}

Jyoti Kaul, Khushbu Jain and Dhirender Olakh. 2019. An Overview on Role of Yellow Maize in Food, Feed and Nutrition Security. Int.J.Curr.Microbiol.App.Sci. 8(02): 3037-3048. doi: https://doi.org/10.20546/ijcmas.2019.802.356 